\title{
FAUNAL RESPONSES to FIRE IN CHAPARRAL AND SAgE SCRUB IN CALIFORNIA, USA
}

\author{
Elizabeth F. van Mantgem ${ }^{1}$, Jon E. Keeley ${ }^{*}, 2$, and Marti Witter ${ }^{3}$ \\ ${ }^{1}$ US Geological Survey, Western Ecological Research Center, \\ Sequoia-Kings Canyon Field Station, \\ 47050 Generals Highway, Three Rivers, California 93271-9651, USA \\ ${ }^{2}$ Department of Ecology and Evolutionary Biology, University of California, \\ 612 Charles E. Young Drive South, Los Angeles, California 90095, USA \\ ${ }^{3}$ National Park Service, Santa Monica Mountains National Recreation Area, \\ 401 West Hillcrest Drive, Thousand Oaks, California 91360, USA \\ *Corresponding author: Tel.:+1-559-565-3170; e-mail: jon_keeley@usgs.gov
}

\section{ABSTRACT}

Impact of fire on California shrublands has been well studied but nearly all of this work has focused on plant communities. Impact on and recovery of the chaparral fauna has received only scattered attention; this paper synthesizes what is known in this regard for the diversity of animal taxa associated with California shrublands and outlines the primary differences between plant and animal responses to fire. We evaluated the primary faunal modes of resisting fire effects in three categories: 1) endogenous survival in a diapause or diapause-like stage, 2) sheltering in place within unburned refugia, or 3) fleeing and recolonizing. Utilizing these patterns in chaparral and sage scrub, as well as some studies on animals in other mediterranean-climate ecosystems, we derived generalizations about how plants and animals differ in their responses to fire impacts and their postfire recovery. One consequence of these differences is
El impacto del fuego sobre los arbustales de California ha sido muy bien estudiado, aunque casi todos esos estudios se han enfocado sobre comunidades vegetales. El impacto sobre, y la recuperación de, la fauna del chaparral, ha recibido sólo una escasa atención; este trabajo sintetiza lo conocido al respecto sobre la diversidad de los taxones animales asociados con los arbustales de California y delinea las diferencias primarias entre las respuestas al fuego de plantas y animales. Evaluamos los modos primarios de la fauna de resistir los efectos del fuego en tres categorías: 1) supervivencia endógena en estado de diapausa o similar, 2) cubriéndose en el lugar dentro de refugios no quemados, o 3) huyendo y recolonizando. Usando esos patrones en el chaparral y en el matorral de California, como así también algunos estudios sobre plantas y animales de otros ecosistemas con clima mediterráneo, derivamos generalizaciones sobre cómo plantas y animales difieren en sus respuestas al impacto del fuego y su recuperación post-fuego. Una consecuencia de esas diferencias es que la variación en el comportamiento del fuego tiene un mayor potencial de afectar animales que plantas. Por ejemplo, las plantas se recuperan del fuego 
that variation in fire behavior has a much greater potential to affect animals than plants. For example, plants recover from fire endogenously from soil-stored seeds and resprouts, so fire size plays a limited role in determining recovery patterns. However, animals that depend on recolonization of burned sites from metapopulations may be greatly affected by fire size. Animal recolonization may also be greatly affected by regional land use patterns that affect colonization corridors, whereas such regional factors play a minimal role in plant community recovery. Fire characteristics such as rate of spread and fire intensity do not appear to play an important role in determining patterns of chaparral and sage scrub plant recovery after fire. However, these fire behavior characteristics may have a profound role in determining survivorship of some animal populations as slow-moving, smoldering combustion may limit survivorship of animals in burrows, whereas fast-moving, high intensity fires may affect survivorship of animals in aboveground refugia or those attempting to flee. Thus, fire regime characteristics may have a much greater effect on postfire recovery of animal communities than plant communities in these shrubland ecosystems. de manera endógena mediante la germinación de semillas o el rebrote de tallos preservados en el suelo, de manera que el tamaño del incendio juega un rol muy limitado en determinar los patrones de recuperación. Por supuesto, los animales que dependen de la recolonización de áreas quemadas provenientes de metapoblaciones pueden ser muy afectados por el tamaño del incendio. La recolonización animal también puede ser muy afectada por el patrón de uso regional de la tierra, que afecta los corredores de colonización, mientras que esos patrones regionales juegan un rol muy menor en la recuperación de las comunidades vegetales. Las características del fuego como velocidad de avance e intensidad no parecen tener un rol importante en determinar los patrones de recuperación de los chaparrales y matorrales después de un incendio. Sin embargo, esas características del comportamiento del fuego pueden tener un rol muy importante para determinar la supervivencia de algunas poblaciones de animales, dado que los fuegos que se desplazan y arden lentamente pueden limitar la supervivencia de animales en cuevas o madrigueras. Por otro lado, los fuegos que se desplazan rápidamente y de alta intensidad pueden afectar la supervivencia de animales en refugios que están sobre el suelo o de aquellos que intentan huir del fuego. Por esas razones y en ecosistemas de arbustales, las características del régimen de fuego puede tener un efecto más pronunciado en la recuperación post-fuego en comunidades animales que en las vegetales.

Keywords: chaparral, endogenous postfire recovery, fauna, fire behavior, recolonization, refugia, sage scrub

Citation: van Mantgem, E.F., J.E. Keeley, and M. Witter. 2015. Faunal responses to fire in chaparral and sage scrub in California, USA. Fire Ecology 11(3): 128-148. doi: 10.4996/ fireecology. 1103128

\section{INTRODUCTION}

Chaparral and sage scrub shrublands in California, USA, are two of the highest diversity plant communities in the world (Richer- son and Lum 1980). Although climate and soil interactions have long been considered responsible for this extraordinary diversity, it is apparent that fire has played a significant role in shaping these communities. Here, as in 
many fire-prone ecosystems, fire is a natural ecosystem process, and artificial perturbations to the fire regime are viewed as ecosystem disturbances. Decades of field studies have laid the framework for understanding vegetation responses to fire; however, animal responses have received far less attention. The purpose of this paper is to review the literature on California's wildlife responses to shrubland fires, and then outline our current understanding of the main differences in plant and animal responses to fire in these ecosystems.

In many ways, wildlife recovery following fire is profoundly different from plant recovery. Most of California's shrubland plant species regenerate endogenously, meaning that they germinate from a seedbank or resprout from vegetative parts already in place, and exogenous sources that might recolonize the site are relatively unimportant (Keeley et al. 2005a). In contrast, the recovery of animal populations after a shrubland wildfire is more variable. We suggest that the diversity of animal responses to fire can be conveniently categorized into one of three types: 1) insect diapause stages such as eggs and pupae are dormant in the soil at the time of fire and lead to rapid postfire regeneration much the way plant seed banks germinate after fire; 2) animals may seek refuge in burrows, rock outcrops, randomly unburned patches, or fire-resistant riparian areas (in essence, they shelter in place); or 3) they either flee the fire or succumb to it and must recolonize from outside the burn perimeter. It is recognized at the outset that populations of some species may fall into more than one of these categories.

We began our synthesis by reviewing published literature on postfire responses of all fauna in chaparral and sage scrub ecosystems (J. Keeley, US Geological Survey, Three Rivers, California, USA, unpublished data). Where instructive, we have included a limited amount of literature on postfire animal responses from other mediterranean-climate shrublands. Our goal was to develop general- izations about how fire impacts different faunal components, how fire behavior characteristics may differentially impact these three functional types, and how postfire recovery varies between these types.

\section{FIRE IMPACTS AND FAUNAL RESPONSES IN CALIFORNIA SHRUBLANDS}

In reviewing the available research on the range of animal groups considered here, we addressed two issues: how fire impacts populations and how populations recover following fire. These two issues are sometimes viewed as either direct or indirect fire responses (Bradstock et al. 2005, Engstrom 2010, Robinson et al. 2013). Direct responses are the immediate, short-term, proximate behaviors by animals during a fire, such as running and hiding, or succumbing to the heat, smoke, and flames. Often there is little research describing these behaviors, and the evidence of fire mortality is typically captured by postfire population spikes or troughs (Quinn 1979, Stromberg 1997, Underwood and Quinn 2010, Driscoll et al. 2012).

Indirect responses concern the means of recovery in the altered postfire environment over time. These responses are influenced by both temporal and spatial variation, including the past history of fire regimes on the site and the pattern and scale of vegetation mosaics present at the time of fire, along with any accompanying faunal metapopulation dynamics (Bradstock et al. 2005, Robinson et al. 2013).

In describing both the direct and indirect responses of animals to fire, we have stratified each taxon into vertical zones that include: subterranean, ground-dwelling, arboreal or aerial, and amphibious fauna (Sugihara et al. 2006). At the outset, we need to recognize that both direct and indirect responses have not been studied for all groups; however, we have tried to capture the level of information available for different groups. 


\section{Arthropods}

Subterranean. The scorpions and solifugids (Class: Arachnida, Order Solifugae) of California's shrublands seem to be largely unaffected by fire, either directly or indirectly (Brown et al. 2010). They are large-bodied, nocturnal generalists that hide in insulated soil and rock burrows during the day, meaning that they do not require the shade of a mature, prefire shrub canopy. Further, they can go without food, hidden away in their burrows for long periods of time, because of a unique physiology allowing them to store energy. Because these animals live insulated underground with caloric reserves, a short-term, crown fire front that is relatively quick, cool, and smokeless is likely harmless to this group of subterranean arthropods. Other fire behaviors such as slow-moving smoldering fires may impact these organisms but there is limited information on these impacts.

In contrast, other mediterranean-climate regions have reported significant differences in soil-arthropod assemblages in burned plots compared to control plots within the first two years after burning (Pryke and Samways 2012, Radea and Arianoutsou 2012, Pitzalis et al. 2013). Interestingly, in Italy, while species composition changed significantly, there was no significant difference in soil-arthropod diversity or evenness between burned and unburned pine forests (Pitzalis et al. 2013). Apparently, species evenness and diversity are affected by fire in independent ways that can lead to an altered soil-arthropod composition, illustrating the complexity of multivariate phenomena. Di Castri (1973) pointed out that, in mediterranean-climate ecosystems, soil animals are heavily influenced by soil humus, which is a function of aboveground vegetation and stand age. The variability in aboveground vegetation and stand age undoubtedly contributes to very different fire behavior patterns with respect to fire regime parameters such as soil humus combustion and rate of spread, fur- ther leading to complexity in predicting fire effects on these organisms.

Ground-dwelling. As with other arthropod groups, studies of the direct effects of fire on ants and spiders are not available in shrubland habitat. However, in a postfire study from adjacent oak woodland following a prescribed fire in California, all ants and spiders recovered within a year (Underwood and Quinn 2010). The slowest were two spiders (Class Arachnida, Order Araneae): diurnal ambush spiders (Family Thomisidae) and night running spiders (Family Gnaphosidae), whose populations remained suppressed for up to nine months after fire. Immediate postfire population spikes were observed, but the authors attributed this to sampling bias, measuring a change in animal activity after the fire of normally cryptic species, rather than measuring a true change in animal numbers. A fiveyear grassland study showed similar results after fire, with an immediate increase in cryptic ant species 14 days after fire, but these recovered to normal abundance one year later (Underwood and Christian 2009). In contrast, seed harvester ant species in this grassland study were initially unaffected at 14 days after fire, increasing significantly by the end of the first year.

Indirect studies show that California native shrubland ant species are only minimally impacted by wildfire, with the exception of the seed-eating harvester ant, Messor andrei Mayr, (Class Insecta, Order Hymenoptera). One postfire study compared several ant species in pre-fire samples to postfire samples collected three years later in coastal sage scrub, chaparral, grassland, and riparian woodland (Matsuda et al. 2011). Populations of only two of the eight ant species changed significantly. These were in coastal sage scrub and had opposite responses: Crematogaster californica Wheeler numbers decreased from $21 \%$ to $2 \%$, while the harvester ant (M. andrei) increased from $<1 \%$ in pre-fire vegetation to $32 \%$ after fire. It follows that these two species may be spe- 
cialized species as evidenced by their response to changes in the habitat structure that resulted from the fire.

The increase in harvester ant numbers also seemed to cause an ant specialist, the horned lizard (Phrynosoma coronatum Blainville), to increase in number, but this observation was not formally quantified (Matsuda et al. 2011). Complicated trophic effects such as this would likely diminish with close proximity to human habitation as fewer harvester ants were found in postfire urban fragments (Suarez et al. 1998). In this case, it was thought that the decreases in native ants might be a result of competition and predation by invasive, irrigation-dependent Argentine ants. In contrast to the decreasing harvester ant numbers, postfire spider and carabid beetle numbers, two other predator groups, were positively correlated with Argentine ant abundance (Bolger et al. 2000).

The Mediterranean omnivorous ant, Aphaenogaster gibbosa Latreille, responded to the changes in temperature and food sources of the postfire environment by altering foraging behavior and diet preferences. This behavioral plasticity was considered key to its survivorship in a diversity of postfire habitats (Lazaro-Gonzalez et al. 2013).

In California chaparral, six ixodid and argasid shrubland tick species were unaffected after a prescribed fire (Class Arachnida, Order Parasitiformes: Ixodes pacificus Cooley \& Kohls, Ixodes jellisoni Cooley \& Kohls, I. spinipalpis Hadwen \& Nuttall, I. woodi Bishop, Dermacentor occidentalis Marx, and D. parumapertus Neumann), as was the soil-dwelling tick Ornithodoros coriaceus Koch. It was concluded that all of the tick species were sheltered in soil refugia during the fire (Padgett et al. 2009).

Arboreal or aerial. Arboreal and aerial insects may survive fire during diapause with below-ground eggs or pupae. For example, the normally arboreal, wingless walking sticks
(Timema cristinae Law \& Crespi, Class Insecta, Order Phasmatoptera) survived the heat of naturally occurring summer and fall chaparral wildfires as diaspores insulated underground from May to December. Diapause is the tough egg stage in the walking stick's lifecycle that lies in the soil, akin to a seed in a plant soil seedbank. If a fire occurs out of season, in the winter or spring, mortality would greatly increase for the unprotected and vulnerable arboreal stages of an active walking stick population, including the larvae, nymphs, and adults that feed or rest on chaparral foliage (Sandoval 2000).

The mutualist pollinating yucca moth (Tegeticula maculata Riley, Class Insecta, Order Lepidoptera) may similarly be partially protected from fires by soil diapause. After pollinating, ovipositing, and feeding on the seeds of its host yucca plant, Hesperoyucca whipplei (Torr.) Blake (formerly Yucca whipplei), the moth larvae emerge from the seeds and drop to the ground to overwinter in a pupal stage underground. Following the October 2003 Cedar Fire in San Diego, California, T. maculata experienced a population crash on a long-term monitoring plot at the Elliot Chaparral Reserve, despite the fact that $90 \%$ of the moth's host yucca plant survived and subsequently flowered normally. As a result of the decline in T. maculata, there was low fruit set and low seed viability in the first year after the fire (D. Udovic, D. Bronstein, and M. Barnes; Institute of Ecology and Evolution, University of Oregon, Eugene, USA, unpublished data). Despite the low population numbers, there was a sufficient reservoir of pupae in the soil to repopulate the area in subsequent years. The yucca moth population gradually recovered over the next two years and yucca fruit production similarly increased (D. Udovic and J. Bronstein, Institute of Ecology and Evolution, University of Oregon, Eugene, USA, unpublished data). The authors pointed out that in a mutualistic system dependent on insect pollination, slow recovery of pollinators could lead 
to a delayed decline in the plant population despite high initial plant survivorship (D. Udovic and J. Bronstein, unpublished data).

The population of a non-pollinating genus of yucca moth, Prodoxus Riley spp., was also significantly reduced after the Cedar Fire, although it was not monitored in the same systematic way as T. maculata. The difference between the two species is that Prodoxus spp. oviposit in the stalks and fleshy tissue surrounding fruits but then pupate there as well, making them a completely arboreal and aerial insect (Darwell et al. 2014). Because all of the yucca stalks were burned in the fire, Prodoxus spp., lacking reservoir soil populations, will likely take longer than $T$. maculata to recover (D. Udovic, Institute of Ecology and Evolution, University of Oregon, Eugene, USA, personal communication). Instead of benefitting from endogenous survival, this genus may only recolonize from unburned yucca stalk refugia.

One of the more phenomenal animal fire responses is that representative of the fire beetle genus Melanophila Eschscholtz (Class Insecta, Order Coleoptera, Family Buprestidae). It finds fires that are still hot via uniquely specialized heat receptors that detect infrared radiation. Even as wood smolders around it, this genus will both breed and then lay eggs in any newly dead wood. But the eggs do not hatch for at least one year. So far in California, this phenomenon has only been documented in conifer forests (Hart 1998) and it remains to be seen if similar species are attracted to chaparral fires.

Winged insect communities are conspicuous between one and four years after a fire. Specifically, they increase in richness and diversity, especially as sunny gaps in the overstory and smoky chemicals encourage fire annuals and herbaceous perennials to grow and flower (Force 1981, 1982, 1990; Potts et al. 2003). In contrast, phytophagous and parasitic hymenopterans only become common after four years postfire, and biting flies, which are quite scarce directly postfire, are only common in mature chaparral (Force 1982, 1990). It is unclear whether this lag time is due to a requirement for changes in resources or a result of long colonization times.

One rare California butterfly is negatively impacted by fire (Marschalek and Deutschman 2008, Marschalek and Klein 2010). The Hermes copper (Lycaena [Hermelycaena] hermes Edwards: Family Lycaenidae) lives in mature coastal sage scrub and chaparral ecosystems in and around San Diego. The butterfly never travels far from its larval host plant, redberry (Rhamnus crocea Nuttall) and adults feed largely on the nectar of California buckwheat, (Eriogonum fasciculatum Bentham), but it will also feed on chamise (Adenostoma fasciculatum Hooker \& Arnott) and tarplant (Deinandra spp. Greene) nectar. The adults emerge from mid-May to early June, to a fairly sessile and territorial life. On average, they only disperse $11 \mathrm{~m}$ to $26 \mathrm{~m}$ in a single flight, but flights as long as $1132 \mathrm{~m}$ have been recorded.

Genetic data suggest that the Hermes copper metapopulation around San Diego has been historically well-linked, despite these short range dispersal patterns. There is concern that urbanization and subsequent habitat fragmentation, particularly in the face of recent large fire events, could result in localized extirpation of some populations in the future (Strahm et al. 2012).

Fruit flies (Family Drosophilidae) were found to be quite resilient to fire, based on postfire surveys of the large 1974 Soboba Fire from an area of previous population surveys in the 1930s and 1940s (Moore et al. 1979). The flies found in the adjacent unburned area reappeared in burned plots almost immediately through recolonization. Sampling in the first season postfire (May to September 1975) showed that species composition remained constant and was similar to that observed nearly 40 years earlier. The only difference was that the 1979 species list included two new species of the obscura group (Drosophila per- 
similis Dobzhansky \& Epling and D. Miranda Dobzhansky) when, previously, D. pseudoobscura Frolova was the only species recorded.

Although comprehensive studies of postfire faunal succession of aerial or arboreal arthropods are lacking for chaparral, such studies in Mediterranean Basin shrublands showed that the community composition of bee pollinators changed as the structural diversity of floral resources changed from herbaceous to woody vegetation (Potts et al. 2003). This suggests that, as California shrubland plant diversity declines after fire (Keeley et al. 2005b), aerial pollinator species richness will follow suit.

At present, we lack sufficient studies to draw conclusions about how invertebrate strata vary in their response to fire. However, there is reason to expect differences among the functional groups. One Australian invertebrate study concluded that surface arthropod assemblages were more resilient to fire than aerial arthropod assemblages, the first recovering in one year and the other in three years, respectively (Pryke and Samways 2012).

\section{Reptiles and Amphibians}

Terrestrial. There is limited data on the direct effects of fire on reptile and amphibian species. Adult western fence lizards (Sceloporus occidentalis Baird \& Girard) are known to survive in insulated refugia, although the juvenile lizards seemed to be negatively impacted by fire (Kahn 1960). Populations of this species also increased significantly after fire (Rochester et al. 2010b), and Kahn (1960) found that chaparral fire had little impact on their food preferences or on female egg laying.

Rochester et al. (2010b) reported that both chaparral and coastal sage scrub herpetofaunal community diversity and composition changed after the large 2003 southern California wildfires. There were increases in some taxa and decreases in others but, overall, these communities remained simplified two years after fire.
They found that the coastal whiptail (Aspidoscelis tigris Baird \& Girard), coast horned lizard (Phrynosoma coronatum Blainville), common side-blotched lizard (Uta stansburiana Blainville), and orange-throated whiptail (Aspidoscelis hyperythra Cope) populations increased after fire. In contrast, the California toad (Anaxyrus boreas halophilus Camp) decreased, as was the case for the southern alligator lizard (Elgaria multicarinata Blainville), garden slender salamander (Batrachoseps major Camp), and several snake species (yellow-bellied racer, Coluber constrictor Linnaeus; California kingsnake, Lampropeltis californiae Blainville; gophersnake, Pituophis catenifer Blainville; and striped racer, Masticophis lateralis Hallowell). It was apparently unclear how much of these community differences were due to patterns of survivorship versus ability to adapt to postfire conditions of cover, soil moisture, and food resources. However, the authors suspect that the more open conditions after fire were largely responsible for the decreased herpetofaunal diversity and that, with repeated fires, these sites might be type converted to grass-shrub mosaics with a depauperate fauna. This is consistent with Lillywhite's (1977) observation of a simplification of the animal community when the shrubland was mechanically and chemically type converted to be more like grassland.

Where there is minimal postfire habitat change or small fire size, the impact of fire can be minimal. In northern California scrub, the effects of a small prescribed burn (65 ha) on western yellow-bellied racers (Coluber constrictor mormon [Baird \& Girard]) were indistinguishable between burned and unburned plots (Thompson et al. 2013). This is consistent with the southern California findings of persistent Coluber populations in grassland and riparian habitat, but reduced populations in more drastically altered postfire shrublands (Rochester et al. 2010b).

Postfire studies in other mediterranean-climate areas provide rich data sources of the 
long-term, indirect responses of herpetofauna to fire (McDonald et al. 2012, Smith et al. 2014). Several Australian studies (Driscoll et al. 2012, Valentine et al. 2012, Elzer et al. 2013, Nimmo et al. 2013, Smith et al. 2013) and two French studies (Santos and Cheylan 2013, Couturier et al. 2014) support the idea that fire response in reptiles and amphibians is species specific rather than consistent across a community (Rochester et al. 2010b, Thompson et al. 2013). Most herpetofauna are successional stage specialists, and the preservation of old-growth habitat is essential for reptile community conservation. For example, the Australian chronosequence study by Nimmo et al.(2013) showed that even 100 years postfire, the shrubland reptile community still did not have a full, pre-burn species composition. Smith et al. (2013) suggested that nocturnal and burrowing animals tended to be "early succession-early postfire" recovery animals, while leaf-litter dwellers tend to be late successional animals.

Amphibious. California newt populations survive fire and their postfire population sizes are similar to prefire levels (Gamradt and Kats 1997). Stromberg (1997) witnessed an example of how individual California newts (Taricha torosa Rathke, in Eschscholtz) might occasionally survive the direct effects of fire. During a prescribed burn in chamise-live oak vegetation, he described two newts who were moving rapidly $\left(\sim 5 \mathrm{~cm} \mathrm{sec}^{-1}\right)$ directly into a 5 $\mathrm{cm}$ to $10 \mathrm{~cm}$ flame front. The slime covering their bodies foamed up, resembling egg meringue. Within 20 to 30 seconds, they were through the flames and on the cooler, black ashes of the litter. Upon close examination, the now crusty white coating easily wiped off their wet bodies. He did not observe any skin blister and the skin color looked normal. Stromberg's conclusion was that foaming of the skin secretions would dissipate heat and could be a mechanism used by this species to survive wildland fires. This protective coating was in some respects like the foam used on homes to prevent their burning. Otherwise, amphibious species are assumed to survive fire by sheltering in place in aquatic or riparian stream habitat, as suggested by the observation of minimal impact of fire on herpetofaunal diversity in riparian habitats (Rochester et al. 2010b).

The most significant threat to amphibious species following large wildfires is loss of aquatic habitat from changes like increased water temperatures, changes in terrestrial food inputs, or from increased postfire erosion, debris flows, and other sedimentation processes. Preferred aquatic habitat of the California newt (pools and runs) was reduced from 37\% to $16 \%$ after a major wildfire in 1993 in the Santa Monica Mountains. While adult population density remained stable, total egg masses were reduced along with the decline in aquatic habitat area (Gamradt and Kats 1997). Interestingly, as the amount of preferred breeding habitat declined, selective pressure on larvae was reduced as food preferences shifted from cannibalism of conspecific larvae to earthworms that increased as a food source from streambank erosion in the first several years postfire (Kerby and Kats 1998).

Some amphibious species, such as the yellow-legged frog (Rana muscosa Camp) and California red-legged frog (Rana draytonii Baird \& Girard), are more vulnerable to sedimentation impacts, which can drastically reduce or locally extirpate populations (Richmond et al. 2013, Backlin et al. 2015). Such fire effects are of special concern for populations at their range boundaries because they threaten the persistence of such species. The red-legged frogs show no evidence that recent fire events have left a genetic imprint in the population, but there was evidence of a 75- to 100 -year old genetic bottleneck that was potentially due to large disturbance events in the past (Richmond et al. 2013). 


\section{Birds}

Although birds can be stratified into ground-dwelling versus aerial species, many species in chaparral overlap in habitat usage, so we will not attempt to sort out these different functional types. In general, birds are likely to survive the direct effects of fire because of their mobility. The exceptions to this are the eggs and nestlings that would be killed in fires that burn in the spring during nesting season. Several recent examples of spring fires, notably the 2009 Jesusita Fire in Santa Barbara, the 2013 Springs Fire in the Santa Monica Mountains, and the May 2014 fires in northern San Diego County, were the result of severe winter droughts.

There are no reported observations of birds sheltering in place in burned shrublands, so recovery is from recolonization of unburned islands or riparian corridors or outside of the burn perimeter. Recolonization is a function of fire size and available metapopulations outside the burn perimeter as well as habitat availability inside the burn perimeter. For example, the special-status California gnatcatcher (Polioptila californica Brewster) prefers old growth coastal sage scrub, with a mix of Artemisia californica Lessing and Eriogonum fasciculatum Bentham, and at least $50 \%$ canopy cover (Beyers and Wirtz II 1995, Akçakaya and Atwood 1997, Atwood et al. 2002). Recovery is a function of the rate of shrub recovery and available habitat outside the burn perimeter. The gnatcatcher is extremely sensitive to fragmentation of the coastal sage scrub vegetation community, leaving it vulnerable to local extinction as the scrub itself is lost (Chase et al. 2000).

Another fragmentation study similarly demonstrates that shrubland obligate birds will become locally extinct over time as increased fire and other disturbances cause the loss of habitat corridors and connectedness within a species' metapopulation (Soule et al. 1988). San Diego County's cactus wren (Campylo- rhynchus brunneicapillus Lafresnaye) is another species at risk of extirpation because of diminishing habitat area and quality. This sedentary species is declining because of habitat loss, fragmentation edge effects in the form of over-predation by Cooper's hawks (Accipiter cooperii Bonaparte), and drought combined with increased fire frequency. According to the Nature Reserve of Orange County, cactus wren populations declined by over $80 \%$ in the last two decades, initially because of catastrophic wildfires (Preston and Kamada 2012).

In contrast to these unique fragmentation studies, Mendelsohn et al. (2008) found that low-elevation coastal sage scrub bird diversity increased after fire, and that the bird community structure changed significantly for both low-elevation chaparral and low-elevation coastal sage scrub, but not for high-elevation shrubland. The shift in community structure for these two low-elevation plant communities was attributed to increases in lazuli buntings (Passerina amoena Say) and spotted towhees (Pipilo maculatus Swainson) in burned chaparral, and postfire decreases of Anna's hummingbirds (Calypte anna Lesson) in chaparral, and wrentits (Chamaea fasciata Gambell) and bushtits (Psaltriparus minimus Townsend) in coastal sage scrub. Additionally, but in contrast to the results in the chaparral, spotted towhee numbers decreased in the burned coastal sage scrub. Wirtz II (1979) reported similarly mixed findings for chaparral birds. With differing study designs, Stanton (1986) and Morearty et al. (1985) had conflicting results with Mendelsohn et al. (2008), reporting decreased bird species richness for burned coastal sage scrub. Stanton (1986) concluded that unburned habitat provided more habitat requirements for more individuals and species of birds throughout the year than the burned areas. Nonresident, migratory species used highly seasonal food sources that were little used by resident species.

At the wildland-urban interface, where there is a human use disturbance gradient (e.g., 
fire, farming, development, recreation, etc.) from wildlands to urban neighborhoods, highest avian diversity occurs with moderate human disturbance in rural or exurban and suburban locations. However, the assortment of avian species in these moderately human-managed sites also comprise widespread generalist species and lack some of the unique localized taxa like the California gnatcatcher, wrentit, bushtit, and cactus wren (Soule 1991; Blair 1996; Sauvajot et al. 1998; Blair 2001a, 2001b; Mitrovich and Hamilton 2007; Preston and Kamada 2012).

In Australia, a 100-year chronosequence study by Watson et al. (2012) showed that mid- and late-succession vegetation ( $>20 \mathrm{yr}$ ) was critical for the recovery of Australian shrubland bird communities. Likewise, Taylor et al. (2012) found that avian species richness was positively associated with increasing amounts of older vegetation in landscapes, but not with the proportion of recently burned vegetation in landscapes. This was verified with a more general small-vertebrate study that included birds: Kelly et al. (2014) warned that maximizing pyrodiversity does not maximize wildlife biodiversity. On the contrary, old-growth vegetation was found to be disproportionately important to wildlife conservation. Robinson et al. (2014) agreed that naturally protected, old-growth refugia are essential for the long-term recovery and stabilization of avian communities after fire. Among Australian researchers, only Sitters et al. (2014) could support the commonly held idea that age class pyrodiversity begets biodiversity for birds, but they recommended increasing the diversity in fire age classes for optimal bird conservation by including both young and oldgrowth vegetation. Faivre et al. (2011) called this "landscape pyrodiversity."

\section{Small Mammals}

In direct response to fire, small mammals must also attempt to either flee or shelter in place. According to Quinn (1979, 1990), animals that perished as a direct result of fire were sometimes burned and sometimes unburned. Typically, animal corpses are found in groups along roads and trails, in small clearings, or in small depressions in the ground, suggesting unsuccessful attempts at sheltering in place or an inability to outrun the fire. The worst of the immediate fire casualties were the dusky-footed woodrats (Neotoma fuscipes Baird), California mice (Peromyscus californicus Gambel), brush rabbits (Sylvilagus bachmani Waterhouse), and California ground squirrels (Spermophilus beecheyi Richardson) (Quinn 1979, 1990).

In contrast, Stephens' kangaroo rats (Dipodomys stephensi Merriam) in grassland and coastal sage scrub (Price and Waser 1984, Magle et al. 2012) were not significantly impacted by fires, perhaps due to sheltering in burrows, coupled with the lower fire intensities in these types of fuels.

The change in habitat after fire favors some small mammals but not others. Increased open habitat favors deer mice, Peromyscus spp., and kangaroo rats, Dipodomys spp., but taxa requiring more closed habitat will recover more slowly, (e.g., the San Diego pocket mouse, Chaetodipus fallax Merriam; desert woodrat, Neotoma lepida Thomas; and brush mouse, Peromyscus boylii Baird) (Lillywhite 1977, Padgett et al. 2009, Brehme et al. 2011). Not surprisingly, as the vegetation recovers, the animal community composition changes with it, and this may be an on-going process for a decade or more. Generalizations at this stage are few; for example, one study showed that even as the initially inflated deer mouse population decreased with plant succession, the postfire abundance of the open-habitat-specialist kangaroo rat continued to rise, doubling from 24 to 43 months after the 2003 Cedar Fire in southern California (Diffendorfer et al. 2012). More recently, Borchert and Borchert (2013) observed that, even 10 years after fire, small animal succession remained in 
flux. It was hypothesized that recolonization might be more successful along the perimeter of a large burn than within the interior (Schwilk and Keeley 1998); however, due to species-specific differences and refugia within burn perimeters, this phenomenon is not easily demonstrated. Indeed, potential safe sites during a fire such as presence of riparian habitat and prevalence of rocky substrate will affect recovery in species-specific ways (Diffendorfer et al. 2012).

In the case of bats, Rochester et al. (2010a) found this extremely mobile taxon to be resilient to large fire events. Despite significant regional variation in community composition, they found no difference in species composition between burned and unburned sites within a community. They concluded that the wide-ranging nature of bats may eliminate local effects within the community.

Although most small mammal species seem to be able to find refugia within burned areas and thus are fairly resilient to natural fire, one notable exception is the Point Reyes mountain beaver (Aplodontia rufa phaea Rafinesque). This species showed little or no recovery five years after the 1995 Vision Fire (Fellers et al. 2004). Based on a $<2 \%$ survival rate (only 19 surviving beavers), the species was found to have been almost eradicated within the fire perimeter, with very little immigration from unburned areas. It was unclear whether this failure to repopulate the burned areas was a result of limited reproductive success in the following years or just unsuitable resources within the burn perimeter (Fellers et al. 2004, Forrestel et al. 2011).

\section{Large Mammals}

Large mammals either survive fire by fleeing ahead of the fire front or succumb to fast moving fires. Recovery requires recolonization from metapopulations outside the fire perimeter. It has long been known that browsing animals such as deer respond favorably to fire with increased populations due the increase in available, more nutritious forage (Gibbens and Schultz 1963, Scrivner et al. 1988, Klinger et al. 1989). Indeed, studies of deer populations that have flocked to new shrub growth on recently burned sites have perpetuated the myth of chaparral senescence in older stands when, in fact, new growth in the older stands is simply produced too high on tall shrubs, beyond the reach of the deer (Keeley and Fotheringham 2001). This same observation has more recently been made for the desert bighorn sheep, Ovis canadensis nelson Merriam, which apparently prefers chaparral that is no more than 15 years old (Bleich et al. 2008, Holl et al. 2012).

Recolonization even after very large fire events does not seem to be an unsurmountable task for many large herbivores and carnivores. Turschak et al. (2010) observed 11 native species after large fire events in 2003 in San Diego County and concluded that mule deer (Odocoileus hemionus Rafinesque), along with carnivores and omnivores such as the mountain lion (Puma concolor Linnaeus), coyote (Canis latrans Say), bobcat (Felis rufus Schreber), badger (Taxidea taxus Schreber), gray fox (Urocyon cinereoargenteus Schreber), raccoon (Procyon lotor Linnaeus), striped skunk (Mephitis mephitis Schreber), spotted skunk (Spilogale gracilis Merriam), opossum (Didelphis virginiana Kerr), and long-tailed weasel (Mustela frenata Lichtenstein) all recovered within three years following a very large wildfire. For most of these species, there was little evidence that relative abundance had changed from the pre-fire levels. Turschak and colleagues suggested that the mobility of these large mammals played a significant role in the ability to recover after large fire events.

More recently, Schuette et al. (2014) reported results similar to Turschak et al. (2010). They observed postfire carnivore numbers from 27 to 43 months after the massive 2003 Cedar Fire in San Diego County and were unable to detect significant differences in occu- 
pancy between unburned and burned plots in gray fox, striped skunk, and bobcat. Only coyotes showed an increase in the burned area, peaking at 34 months after the fire. In this study, as in others, the lag time between the fire and the initiation of postfire wildlife monitoring limited the ability to evaluate how the rate and spatial pattern of recolonization contributed to the observed population changes. Population recovery was attributed to their mobility and behavioral plasticity with respect to habitat structure and diet.

Recolonization of burned sites is dependent on metapopulation dynamics outside the burn perimeter. In high human density landscapes such as southern California, this is a particular challenge because habitat fragmentation may eliminate parts of some metapopulations and disrupt corridors for recolonization. Crooks and Soule (1999) documented how small, isolated shrubland fragments, disconnected by large areas of urbanization, lost their larger carnivore species over time. The fragments that were isolated from larger core areas of habitat the longest were no longer visited by any native carnivores, even though research shows that coyote populations can thrive in close proximity to humans (Fedriani et al. 2001, Gehrt and Riley 2010). The difference here may be that the enhanced coyote population was still connected to the coyote metapopulation; however, more recent research shows a more variable response by coyotes to humans and fire in a rural environment (Schuette et al. 2014). In the Crooks and Soule (1999) study, within the most disturbed of the disconnected urban fragments, the last remaining hunter was always the human subsidized super-predator, the ubiquitous house cat, which has a cascading effect on bird and mammal populations. This study illustrates that, as habitat fragments deteriorate over time, the resilience of large mammals to fire is further impaired.

\section{DISCUSSION}

The literature reviewed here is summarized in Table 1, along with our understanding of how each of the taxa fit our hypothesized categories of fire response: 1) endogenous regeneration from diapause or diapause-like stages in the soil, 2) sheltering in place within unburned refugia, or 3) fleeing and recolonization.

In general, many soil- and ground-dwelling arthropods survive fire endogenously from dormant soil-stored stages, much like plants. For example, insects like walking sticks and yucca moths seem to endure seasonal shrubland fires as resistant diapause structures. There is little direct evidence for this fire survival strategy in other arthropod species; however, based on life histories, it is likely that it applies to many others. Because endogenous survival (of both plants and animals) is also a useful survival strategy for the summer and fall drought of the mediterranean-type climate, it is perhaps best viewed as an ecosystem adaptation to seasonality rather than a fire-specific response (Keeley et al. 2011).

Animals that shelter in place in unburned refugia such as burrows, rocks, riparian areas, or unburned patches include many small vertebrates (reptiles, amphibians, and small mammals) and arthropods. While some refugia such as burrows, rocks, and riparian areas are predictable refugia, other unburned islands within the fire perimeter will depend on fire behavior, and thus their spatial distribution will be unpredictable. These patches are known as stochastic refugia and don't have any inherent qualities making them fire resistant (Robinson et al. 2013, New 2014).

The larger or more mobile animals that flee a fire need to find adequate shelter outside the fire perimeter until conditions are suitable for recolonization. Thus, regional patterns of land use and extent of habitat fragmentation will be particularly important to these species. Recolonizing burned areas will depend on the distribution of metapopulations and patterns of suitable corridors. 
Table 1. Summary of animal responses to fire keyed to the literature within our three hypothesized functional categories.

\begin{tabular}{|c|c|c|c|c|}
\hline & Literature & $\begin{array}{l}\text { Endogenous } \\
\text { regeneration }\end{array}$ & $\begin{array}{c}\text { Shelter } \\
\text { in refugia }\end{array}$ & Recolonization \\
\hline \multicolumn{5}{|l|}{ Arthropods } \\
\hline \multicolumn{5}{|l|}{ Subterranean } \\
\hline Scorpions and solifugids & 1 & $\mathrm{XXX}$ & & \\
\hline \multicolumn{5}{|l|}{ Ground-dwelling } \\
\hline Spiders & 2 & XXX & & \\
\hline Ticks & 3 & $\mathrm{XXX}$ & & \\
\hline Ants & $4,5,6,7$ & $\mathrm{XXX}$ & & \\
\hline \multicolumn{5}{|l|}{ Arboreal or aerial } \\
\hline Walking sticks & 8 & $\mathrm{XXX}$ & & \\
\hline Yucca moths & $9,10,11$ & $\mathrm{XXX}$ & & \\
\hline Fire beetles & 12 & & & XXX \\
\hline $\begin{array}{l}\text { Pollinators, parasites, } \\
\text { and biting flies }\end{array}$ & $3,14,15,16$ & XXX & & XXX \\
\hline Hermes copper & $17,18,19$ & XXX & & XXX \\
\hline Drosophila & 20 & XXX & & $\mathrm{XXX}$ \\
\hline Other aerial insects & 21,22 & XXX & & XXX \\
\hline \multicolumn{5}{|l|}{ Reptiles and amphibians } \\
\hline Terrestrial & $23-35$ & & XXX & \\
\hline Amphibians & $36-39$ & & $\mathrm{XXX}$ & $\mathrm{XXX}$ \\
\hline Birds & $40-59$ & & & XXX \\
\hline Small mammals & $, 25,60-69$ & & XXX & XXX \\
\hline Large mammals & $70-77$ & & & $\mathrm{XXX}$ \\
\hline $1=$ Brown et al. 2010 & \multicolumn{2}{|c|}{$22=$ Pryke and Samways 2012} & \multicolumn{2}{|c|}{$50=$ Soule 1991} \\
\hline $2=$ Underwood and Quinn 2010 & \multicolumn{2}{|c|}{$23=$ Kahn 1960} & \multicolumn{2}{|c|}{$51=$ Blair 1996} \\
\hline $3=$ Padgett et al. 2009 & \multicolumn{2}{|c|}{$24=$ Rochester et al. $2010 b$} & \multicolumn{2}{|c|}{$52=$ Sauvajot et al. 1998} \\
\hline 4 = Matsuda et al. 2011 & \multicolumn{2}{|c|}{$25=$ Lillywhite 1977} & \multicolumn{2}{|c|}{$53=$ Blair 2001 $a, b$} \\
\hline $5=$ Suarez et al. 1998 & \multicolumn{2}{|c|}{$26=$ Thompson et al. 2013} & \multicolumn{2}{|c|}{$54=$ Mitrovich and Hamilton 2007} \\
\hline $6=$ Bolger et al. 2000 & \multicolumn{2}{|c|}{$27=$ Driscoll et al. 2012} & \multicolumn{2}{|c|}{$55=$ Preston and Kamada 2012} \\
\hline $7=$ Lazaro-Gonzalez et al. 2013 & \multicolumn{2}{|c|}{$28=$ McDonald et al. 2012} & \multicolumn{2}{|c|}{$56=$ Watson et al. 2012} \\
\hline $8=$ Sandoval 2000 & \multicolumn{2}{|c|}{$29=$ Valentine et al. 2012} & \multicolumn{2}{|c|}{$57=$ Taylor et al. 2012} \\
\hline $9=$ D. Udovic, Institute of Ecology and & \multicolumn{2}{|c|}{$30=$ Elzer et al. 2013} & $58=$ Robins & l. 2014 \\
\hline Evolution, University of Oregon, Eu- & $\mathrm{u}-31=\mathrm{Nimm}$ & al. 2013 & $59=$ Sitters $\epsilon$ & 014 \\
\hline gene, USA, personal communication & on $32=$ Smith & 2013 & $60=$ Quinn 1 & \\
\hline $10=\mathrm{D}$. Udovic D. Bronstein, and M. & $33=$ Smith & 2014 & $61=$ Quinn 1 & \\
\hline Barnes; Institute of Ecology and & $34=$ Santos & Cheylan 2013 & $62=$ Price ar & er 1984 \\
\hline Evolution, University of Oregon, & $35=$ Coutu & tal. 2014 & $63=$ Magle $\epsilon$ & 012 \\
\hline Eugene, USA, unpublished data & $36=$ Strom & 1997 & $64=$ Brehme & 2011 \\
\hline $11=\mathrm{D}$. Udovic and J. Bronstein, Institute of & f $37=$ Gamra & ad Kats 1997 & $65=$ Diffend & et al. 2012 \\
\hline Ecology and Evolution, University of & $38=$ Kerby & Kats 1998 & $66=$ Borche & Borchert 2013 \\
\hline Oregon, Eugene, USA, unpublished data & ata $39=$ Richm & et al. 2013 & $67=$ Schwill & Keeley 1998 \\
\hline $12=$ Hart 1998 & $40=$ Beyer & Wirtz II 1995 & $68=$ Roches & l. $2010 a$ \\
\hline $13=$ Force 1981 & $41=$ Akçak & and Atwood 1997 & $69=$ Fellers & 2004 \\
\hline $14=$ Force 1982 & $42=$ Atwoo & al. 2002 & $70=$ Gibben & Schultz 1963 \\
\hline $15=$ Force 1990 & $43=$ Chase & 2000 & $71=$ Keeley & theringham 2001 \\
\hline $16=$ Potts et al. 2003 & $44=$ Soule & 1988 & $72=$ Bleich & 008 \\
\hline $17=$ Marschalek and Deutschman 2008 & $45=$ Presto & Kamada 2012 & $73=$ Holl et & \\
\hline $18=$ Marschalek and Klein 2010 & $46=$ Mend & n et al. 2008 & $74=$ Turscha & 1. 2010 \\
\hline $19=$ Strahm et al. 2012 & $47=$ Wirtz & & $75=$ Schuett & 2014 \\
\hline $20=$ Moore et al. 1979 & $48=$ Stanto & & $76=$ Crooks & oule 1999 \\
\hline $21=$ Keeley et al. 2005a,b & $49=$ Morea & tal. 1985 & $77=$ Fedrian & 2001 \\
\hline
\end{tabular}


There are good reasons for believing that these animal functional types differ markedly from plants in their response to fire regime characteristics (Table 2 ). The primary parameter that drives different plant responses is fire frequency (Keeley et al. 2012). Although plants in this ecosystem can tolerate very long fire return intervals, and this includes postfire specialist annuals, much of the flora is poorly adapted to frequent fires. However, a change in fire frequency likely affects animals indirectly as the habitat changes.

For our three wildlife functional groups, the other four fire regime characteristics: size, rate of spread, intensity, and season, seem immediately significant during a fire, particularly for the animals that shelter in place. Changing fire's speed or intensity may overheat soil-insulated animals. An increase in fire size or speed may make escape or recolonization impossible for large- or medium-sized animals. Possibly the most damaging, a change in fire season may affect vulnerable stages of nest building, offspring rearing, or juvenile survival for all three wildlife functional groups.

Depending on a species' ability to utilize the fire-transformed landscape, recolonization back into the burned area will be rapid or slow as the vegetation follows its successional pathway (Figure 1). Early seral stage specialists and generalists will appear within a burn area immediately, while others may take years to recover. Colonizers also include those species that do not escape, but experience complete mortality and only re-establish in the burn area by recolonization from unburned metapopulations. For the aerial insects that seem to take the longest to repopulate a burned area (e.g., biting flies, butterflies, and non-pollinating yucca moth species), escape in combination with recolonization may be their primary fire survival strategy.

It follows that no single fire regime will generate highest biodiversity as different taxa peak at different times after fire. Instead of managing for a single fire regime, sustainability of total biodiversity in California shrublands will require a landscape that, in both space and time, includes different lengths of time since fire and, especially, adequate cover of oldgrowth chaparral and coastal sage scrub (Faivre et al. 2011, Robinson et al. 2013, Kelly et al. 2014). As mentioned previously, Faivre et al. (2011) call this "landscape pyrodiversity." For California shrublands, determining the right balance between old-growth ecosystems and younger, seral stage shrublands to maximize biodiversity should be an important focus of future research (Kelly et al. 2014).

Table 2. Fire regime characteristics that are significant to plant and animal survival and recovery.

\begin{tabular}{lcccc}
\hline \multirow{2}{*}{$\begin{array}{l}\text { Fire regime } \\
\text { parameter }\end{array}$} & Plants & Endogenous diapause & Shelter in refugia & Flee and recolonize \\
\cline { 3 - 5 } & $\mathrm{X}$ & & & \\
\hline Frequency & & $\mathrm{X}$ & $\mathrm{X}$ \\
Size or patchiness & & $\mathrm{X}$ & $\mathrm{X}$ \\
Rate of spread & & $\mathrm{X}$ & $\mathrm{X}$ & \\
Intensity & $\mathrm{X}$ & & $\mathrm{X}$ \\
Season & $\mathrm{X}$ & & & \\
\hline
\end{tabular}




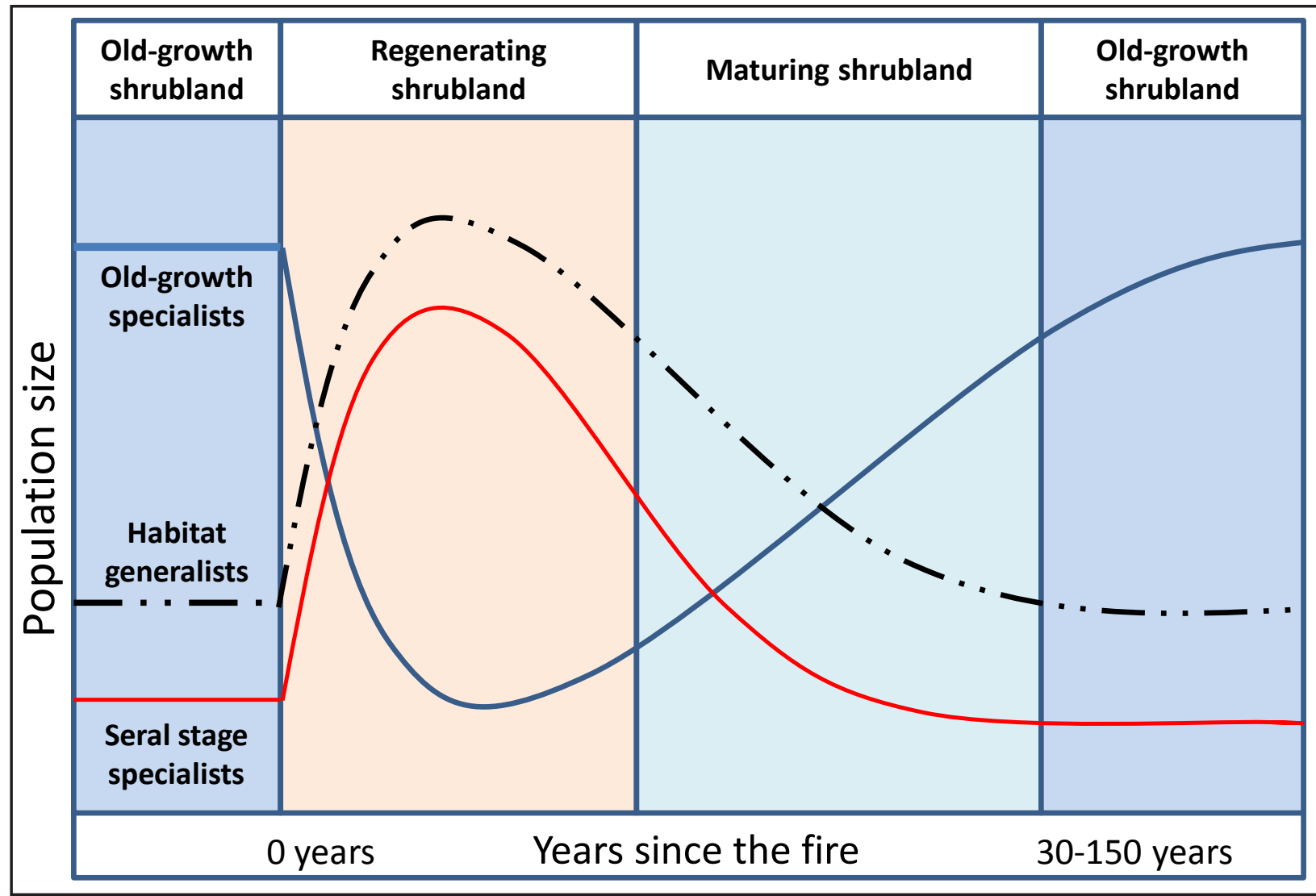

Figure 1. With disturbances such as fire, different species recover at different rates over time. Overall, generalists such as edge and open-site species will initially thrive with the disturbance and then decline. In contrast, specialists such as understory and old-growth species will do the opposite, taking a much longer time to recover to pre-fire population numbers.

\section{ACKNOWLEDGEMENTS}

This work was supported in part by the California Fire Science Consortium, funded through the Joint Fire Sciences Program. It was also supported by the US Geological Survey and the National Park Service. Special thanks go to P. van Mantgem, E. Boydston, R. Blair, D. Udovic, M. Price, M. Mendelsohn, M. Mitrovich, W. Spencer, C. Rochester, and M. Jennings for providing useful information, citations, review, and comments.

\section{LITERATURE CITED}

Akçakaya, H.R., and J. L. Atwood. 1997. A habitat-based metapopulation model of the California gnatcatcher. Conservation Biology 11: 422-434. doi: 10.1046/j.1523-1739.1997.96164.x

Atwood, J.L., A.D. Pairis, M.R. Fugagli, and C.A. Reynolds. 2002. Effects of fire on California gnatcatcher populations on Camp Pendleton Marine Corps Base: final report. Antioch New England Institute, Keene, New Hampshire, USA.

Backlin, A.R., C.J. Hitchcock, E.A. Gallegos, J.L. Yee, and R.N. Fisher. 2015. The precarious persistence of the endangered Sierra Madre yellow-legged frog Rana muscosa in southern California, USA. Oryx 49: 157-164. doi: 10.1017/S003060531300029X 
Beyers, J.L., and W.O. Wirtz II. 1995. Vegetative characteristics of coastal sage scrub sites used by California gnatcatchers: implications for management in a fire-prone ecosystem. Pages 81-89 in: J.A. Greenlee, editor. Proceedings of the Fire Effects on Rare and Endangered Species and Habitats Conference. International Association of Wildland Fire, 13-16 November 1995, Coeur d'Alene, Idaho, USA.

Blair, R.B. 1996. Land use and avian species diversity along an urban gradient. Ecological Applications 6: 506-519. doi: 10.2307/2269387

Blair, R.B. 2001a. Birds and butterflies along urban gradients in two ecoregions of the United States: is urbanization creating a homogenous fauna? Pages 33-56 in: J.L. Lockwood and M.L. McKinneys, editors. Biotic homogenization: the loss of diversity through invasion and extinction. Springer, New York, New York, USA. doi: 10.1007/978-1-4615-1261-5_3

Blair, R.B. 2001b. Creating a homogenous avifauna: local extinction and invasion along urban gradients in California and Ohio. Pages 459-486 in J. Marzluff, K. McGowan, and R. Bowman, editors. Avian ecology in an urbanizing world. Springer, New York, New York, USA.

Bleich, V.C., H. Johnson, S.A. Holl, L. Konde, G. Torres, and P.R. Krausman. 2008. Fire history in a chaparral ecosystem: implication for conservation of a native ungulate. Rangeland Ecology \& Management 61: 571-579. doi: 10.2111/07-016.1

Bolger, D.T., A.V. Suarez, K.R. Crooks, S.A. Morrison, and T.J. Case. 2000. Arthropods in urban habitat fragments in southern California: area, age, and edge effects. Ecological Applications 10: 1230-1248. doi: 10.1890/1051-0761(2000)010[1230:AIUHFI]2.0.CO;2

Borchert, M., and S.M. Borchert. 2013. Small mammal use of the burn perimeter following a chaparral wildfire in southern California. Southern California Academy of Sciences 112: 6373. doi: 10.3160/0038-3872-112.2.63

Bradstock, R., M. Bedward, A. Gill, and J. Cohn. 2005. Which mosaic? A landscape ecological approach for evaluating interactions between fire regimes, habitat and animals. Wildlife Research 32: 409-423. doi: 10.1071/WR02114

Brehme, C.S., D.R. Clark, C.J. Rochester, and R.N. Fisher. 2011. Wildfires alter rodent community structure across four vegetation types in southern California, USA. Fire Ecology 7(2): 81-96. doi: 10.4996/fireecology.0702081

Brown, C.W., M.J. Mitrovich, C. Rochester, and R. Fisher. 2010. Effects of large-scale wildfires on the scorpion and solifugid communities of the San Diego MSCP region. Data Summary prepared for San Diego Association of Governments. US Geological Survey, Sacramento, California, USA.

Chase, M.K., W.B. Kristan III, A.J. Lynam, M.V. Price, and R.T. Rotenberry. 2000. Single species as indicators of species richness and composition in California coastal sage scrub birds and small mammals. Conservation Biology 14: 474-487. doi: 10.1046/j.1523-1739.2000.98312.x

Couturier, T., A. Besnard, A. Bertolero, V. Bosc, G. Astruc, and M. Cheylan. 2014. Factors determining the abundance and occurrence of Hermann's tortoise, Testudo hermanni, in France and Spain: fire regime and landscape changes as the main drivers. Biological Conservation 170: 177-187. doi: 10.1016/j.biocon.2013.12.028

Crooks, K.R., and M.E. Soule. 1999. Mesopredator release and avifaunal extinctions in a fragmented system. Nature 400: 563-566. doi: 10.1038/23028

Darwell, C., K. Fox, and D. Althoff. 2014. The roles of geography and founder effects in promoting host-associated differentiation in the generalist bogus yucca moth Prodoxus decipiens. Journal of Evolutionary Biology 27: 2706-2718. doi: 10.1111/jeb.12529 
di Castri, F. 1973. Soil animals in latitudinal and topographical gradients of mediterranean ecosystems. Pages 171-190 in: F. di Castri and H.A. Mooney, editors. Mediterranean type ecosystems. Origin and structure. Springer-Verlag, New York, New York, USA. doi: 10.1007/978-3-642-65520-3_11

Diffendorfer, J., G.M. Fleming, S. Tremor, W. Spencer, and J.L. Beyers. 2012. The role of fire severity, distance from fire perimeter and vegetation on post-fire recovery of small-mammal communities in chaparral. International Journal of Wildland Fire 21: 436-448. doi: 10.1071/ WF10060

Driscoll, D.A., A.L. Smith, S. Blight, and J. Maindonald. 2012. Reptile responses to fire and the risk of post-disturbance sampling bias. Biodiversity and Conservation 21: 1607-1625. doi: 10.1007/s10531-012-0267-5

Elzer, A.L., D.A. Pike, J.K. Webb, K. Hammill, R.A. Bradstock, and R. Shine. 2013. Forest-fire regimes affect thermoregulatory opportunities for terrestrial ectotherms. Austral Ecology 38: 190-198. doi: 10.1111/j.1442-9993.2012.02391.x

Engstrom, R. 2010. First-order fire effects on animals: review and recommendations. Fire Ecology 6(1): 115-130. doi: 10.4996/fireecology.0601115

Faivre, N., P. Roche, M.M. Boer, L. McCaw, and P.F. Grierson. 2011. Characterization of landscape pyrodiversity in mediterranean environments: contrasts and similarities between south-western Australia and south-eastern France. Landscape Ecology 26: 557-571. doi: 10.1007/s10980-011-9582-6

Fedriani, J.M., T.K. Fuller, and R.M. Sauvajot. 2001. Does availability of anthropogenic food enhance densities of omnivorous mammals? An example with coyotes in southern California. Ecography 24: 325-331. doi: 10.1111/j.1600-0587.2001.tb00205.x

Fellers, G.M., D. Pratt, and J.L. Griffin. 2004. Fire effects on the Point Reyes mountain beaver at Point Reyes National Seashore, California. The Journal of Wildlife Management 68: 503508. doi: 10.2193/0022-541X(2004)068[0503:FEOTPR]2.0.CO;2

Force, D.C. 1981. Postfire insect succession in southern California chaparral. American Naturalist 117: 575-582. doi: 10.1086/283742

Force, D.C. 1982. Postburn insect fauna in southern California chaparral. Pages 234-240 in: C.E. Conrad and W.C. Oechel, editors. Proceedings of the symposium on dynamics and management of mediterranean-type ecosystems. USDA Forest Service General Technical Report PSW-58, Pacific Southwest Research Station, Albany, California, USA.

Force, D.C. 1990. Ecology of insects in California chaparral. USDA Forest Service Research Paper PSW-201, Pacific Southwest Research Station, Albany, California, USA.

Forrestel, A.B., M.A. Moritz, and S.L. Stephens. 2011. Landscape-scale vegetation change following fire in Point Reyes, California, USA. Fire Ecology 7(2): 114-128. doi: 10.4996/ fireecology.0702114

Gamradt, S.C. and L.B. Kats. 1997. Impact of chaparral wildfire-induced sedimentation on oviposition of stream-breeding California newts (Taricha torosa). Oecologia 110: 546-549. doi: $10.1007 / \mathrm{s} 004420050193$

Gehrt, S.D., and S.P.D. Riley. 2010. Coyotes (Canis latrans). Pages 79-95 in S.D. Gehrt, S.P.D. Riley, and B.L. Cypher, editors. Urban carnivores: ecology, conflict, and conservation. Johns Hopkins University Press, Baltimore, Maryland, USA.

Gibbens, R., and A. Schultz. 1963. Brush manipulation on a deer winter range. California Fish and Game 49: 95-118.

Hart, S. 1998. Beetle mania: an attraction to fire. BioScience 48: 3-5. doi: 10.2307/1313221 
Holl, S.A., V.C. Bleich, B.W. Callenberger, and B. Bahro. 2012. Simulated effects of two fire regimes on bighorn sheep: the San Gabriel Mountains, California, USA. Fire Ecology 8(3): 88-103. doi: 10.4996/fireecology.0803088

Kahn, W.C. 1960. Observations on the effect of a burn on a population of Sceloporus occidentalis. Ecology 41: 358-359. doi: 10.2307/1930227

Keeley, J., J. Pausas, P. Rundel, W. Bond, and R. Bradstock. 2011. Fire as an evolutionary pressure shaping plant traits. Trends in Plant Science 16: 406-411. doi: 10.1016/j. tplants.2011.04.002

Keeley, J.E., W.J. Bond, R.A. Bradstock, J.G. Pausas, and W. Rundel. 2012. Fire in mediterranean climate ecosystems: ecology, evolution and management. Cambridge University Press, Cambridge, England, United Kingdom.

Keeley, J.E. and C.J. Fotheringham. 2001. Historic fire regime in southern California shrublands. Conservation Biology 15: 1536-1548. doi: 10.1046/j.1523-1739.2001.00097.x

Keeley, J.E., C.J. Fotheringham, and M. Baer-Keeley. 2005a. Determinants of postfire recovery and succession in mediterranean-climate shrublands of California. Ecological Applications 15: 1515-1534. doi: 10.1890/04-1005

Keeley, J.E., C.J. Fotheringham, and M. Baer-Keeley. 2005b. Factors affecting plant diversity during postfire recovery and succession of mediterranean-climate shrublands in California, USA. Diversity and Distributions 11: 535-537. doi: 10.1111/j.1366-9516.2005.00200.x

Kelly, L.T., A.F. Bennett, M.F. Clarke, and M.A. McCarthy. 2014. Optimal fire histories for biodiversity conservation. Conservation Biology 29: 473-481. doi: 10.1111/cobi.12384

Kerby, J., and L. Kats. 1998. Modified interactions between salamander life stages caused by wildfire-induced sedimentation. Ecology 79: 740-745. 10.1890/0012-9658(1998)079[0740:MIBSLS]2.0.CO;2

Klinger, R.C., M.J. Kutilek, and H.S. Shellhammer. 1989. Population responses of black-tailed deer to prescribed burning. The Journal of Wildlife Management 53: 863-871. doi: $10.2307 / 3809578$

Lazaro-Gonzalez, A., X. Arnan, R. Boulay, X. Cerda, and A. Rodrigo. 2013. Short-term ecological and behavioural responses to wildfire of a Mediterranean ant species, Aphaenogaster gibbosa (Latr. 1978). Insect Conservation \& Diversity 6: 627-638. doi: 10.1111/icad.12018

Lillywhite, H.B. 1977. Effects of chaparral conversion on small vertebrates in southern California. Biological Conservation 11: 171-184. doi: 10.1016/0006-3207(77)90002-7

Magle, S.B., V.M. Hunt, M. Vernon, and K.R. Crooks. 2012. Urban wildlife research: past, present, and future. Biological Conservation 155: 23-32. doi: 10.1016/j.biocon.2012.06.018

Marschalek, D.A., and D.H. Deutschman. 2008. Hermes copper (Lycaena [Hermelycaena] hermes: Lycaenidae): life history and population estimation of a rare butterfly. Journal of Insect Conservation 12: 97-105. doi: 10.1007/s10841-006-9064-3

Marschalek, D.A., and M.W. Klein. 2010. Distribution, ecology, and conservation of Hermes copper (Lycaenidae: Lycaena [Hermelycaena] hermes). Journal of Insect Conservation 14: 721-730. doi: 10.1007/s10841-010-9302-6

Matsuda, T., G. Turschak, C. Brehme, C. Rochester, M. Mitrovich, and R. Fisher. 2011. Effects of large-scale wildfires on ground foraging ants (Hymenoptera: Formicidae) in southern California. Environmental Entomology 40: 204-216. doi: 10.1603/EN10061

McDonald, P.J., G.W. Luck, C.R. Pavey, and S. Wassens. 2012. Importance of fire in influencing the occurrence of snakes in an upland region of arid Australia. Austral Ecology 37: 855-864. doi: 10.1111/j.1442-9993.2011.02348.x 
Mendelsohn, M.B., C.S. Brehme, C.J. Rochester, D. C. Stokes, S.A. Hathaway, and R.N. Fisher. 2008. Responses in bird communities to wildland fires in southern California. Fire Ecology 4: 63-82. doi: 10.4996/fireecology.0402063

Mitrovich, M.J., and R.A. Hamilton. 2007. Status of the cactus wren (Campylorhynchus brunneicapillus) within the coastal subregion of Orange County, California. Report prepared for the Nature Reserve of Orange County, Irvine, California, USA. <http://www.naturereserveoc. org/NROC\%202006\%20Cactus\%20Wren\%20Status\%20Report.pdf>. Accessed 15 October 2015.

Moore, J.A., C.E. Taylor, and B.C. Moore. 1979. The Drosophila of southern California. I. Colonization after a fire. Evolution 33: 156-171. doi: 10.2307/2407373

Morearty, D.J., R.E. Farris, D.K. Noda, and P.A. Stanton. 1985. Effects of fire on a coastal sage scrub bird community. The Southwestern Naturalist 30: 452-453. doi: 10.2307/3671284

New, T.R. 2014. Insects, fire and conservation. Springer International Publishing, Cham, Switzerland. doi: 10.1007/978-3-319-08096-3

Nimmo, D., L. Kelly, L. Spence-Bailey, S. Watson, R. Taylor, M. Clarke, and A. Bennett. 2013. Fire mosaics and reptile conservation in a fire-prone region. Conservation Biology 27: 345353. doi: 10.1111/j.1523-1739.2012.01958.x

Padgett, K., L. Casher, S. Stephens, and R. Lane. 2009. Effect of prescribed fire for tick control in California chaparral. Journal of Medical Entomology 46: 1138-1145. doi: 10.1603/033.046.0522

Pitzalis, M., M.A. Bologna, and L. Luiselli. 2013. Is evenness altered by fire in natural assemblages of soil arthropods? Acta Oecologica 49: 64-70. doi: 10.1016/j.actao.2013.03.001

Potts, S.G., B. Vulliamy, A. Dafni, G. Ne'eman, C. O’Toole, S. Roberts, and P. Willmer. 2003. Response of plant-pollinator communities to fire: changes in diversity, abundance and floral reward structure. Oikos 101: 103-112. doi: 10.1034/j.1600-0706.2003.12186.x

Preston, K., and D. Kamada. 2012. Nature Reserve of Orange County: monitoring coastal cactus wren reproduction, dispersal and survival, 2009-2011. California Department of Fish and Game, San Diego, California, USA.

Price, M.V., and N.M. Waser. 1984. On the relative abundance of species: postfire changes in a coastal sage scrub rodent community. Ecology 65: 1161-1169. doi: 10.2307/1938324

Pryke, J.S. and M.J. Samways. 2012. Differential resilience of invertebrates to fire. Austral Ecology 37: 460-469. doi: 10.1111/j.1442-9993.2011.02307.x

Quinn, R.D. 1979. Effects of fire on small mammals in the chaparral. Pages 125-133 in: D.L. Koch, editor. Proceedings of the Cal-Neva Wildlife Transactions. The Wildlife Society, 1-3 February 1979, Long Beach, California, USA.

Quinn, R.D. 1990. Habitat preferences and distribution of mammals in California chaparral. USDA Forest Service Research Paper PSW-202, Pacific Southwest Research Station, Berkeley, California, USA.

Radea, C., and M. Arianoutsou. 2012. Soil arthropod communities and population dynamics following wildfires in pine forests of the Mediterranean Basin: a review. Israel Journal of Ecology \& Evolution 58: 137-149.

Richerson, P., and K. Lum. 1980. Patterns of plant species diversity in California: relation to weather and topography. American Naturalist 116: 504-536.

Richmond, J.Q., K.R. Barr, A.R. Backlin, A.G. Vandergast, and R.N. Fisher. 2013. Evolutionary dynamics of a rapidly receding southern range boundary in the threatened California redlegged frog (Rana draytonii). Evolutionary Applications 6: 808-822. doi: 10.1111/eva.12067 
Robinson, N.M., S.W. Leonard, A.F. Bennett, and M.F. Clarke. 2014. Refuges for birds in fireprone landscapes: the influence of fire severity and fire history on the distribution of forest birds. Forest Ecology and Management 318: 110-121. doi: 10.1016/j.foreco.2014.01.008

Robinson, N.M., S.W. Leonard, E. Ritchie, M. Bassett, E. Chia, S. Buckingham, H. Gibb, A. Bennett, and M. Clarke. 2013. Refuges for fauna in fire-prone landscapes: their ecological function and importance. Journal of Applied Ecology 50: 1321-1329. doi: 10.1111/ 1365-2664.12153

Rochester, C.J., A.R. Backlin, D.C. Stokes, M.J. Mitrovich, C.S. Brehme, and R.N. Fisher. 2010a. Bat communities of Rancho Jamul Ecological Reserve and Santa Ysabel Open Space Preserve before and after the 2003 wildfires. Data Summary prepared for San Diego Association of Governments. US Geological Survey, Sacramento, California, USA.

Rochester, C.J., C.S. Brehme, D.R. Clark, D.C. Stokes, S.A. Hathaway, and R.N. Fisher. $2010 b$. Reptile and amphibian responses to large-scale wildfires in southern California. Journal of Herpetology 44: 333-351. doi: 10.1670/08-143.1

Sandoval, C. 2000. Persistence of a walking-stick population (Phasmatoptera: Timematodea) after a wildfire. Southwestern Naturalist 4: 123-127. doi: 10.2307/3672452

Santos, X., and M. Cheylan. 2013. Taxonomic and functional response of a Mediterranean reptile assemblage to a repeated fire regime. Biological Conservation 168: 90-98. doi: 10.1016/j.biocon.2013.09.008

Sauvajot, R.M., M. Buechner, D.A. Kamradt, and C.M. Schonewald. 1998. Patterns of human disturbance and response by small mammals and birds in chaparral near urban environment. Urban Ecosystems 2: 279-297. doi: 10.1023/A:1009588723665

Schuette, P., J. Diffendorfer, D. Deutschman, S. Tremor, and W. Spencer. 2014. Carnivore distributions across chaparral habitats exposed to wildfire and rural housing in southern California. International Journal of Wildland Fire 23: 591-600. doi: 10.1071/WF13062

Schwilk, D.W. and J.E. Keeley. 1998. Rodent populations after a large wildfire in California chaparral and coastal sage scrub. The Southwestern Naturalist 43: 480-483.

Scrivner, J.H., C.E. Vaughn, and M.B. Jones. 1988. Mineral concentrations of black-tailed deer diets in California chaparral. The Journal of Wildlife Management 52: 37-41. doi: $10.2307 / 3801054$

Sitters, H., F. J. Christie, J. Di Stefano, M. Swan, T. Penman, P.C. Collins, and A. York. 2014. Avian responses to the diversity and configuration of fire age classes and vegetation types across a rainfall gradient. Forest Ecology and Management 318: 13-20. doi: 10.1016/j.foreco.2014.01.009

Smith, A.L., C.M. Bull, M.G. Gardner, and D.A. Driscoll. 2014. Life history influences how fire affects genetic diversity in two lizard species. Molecular Ecology 23: 2428-2441. doi: $10.1111 / \mathrm{mec} .12757$

Smith, A.L., C. Michael Bull, and D.A. Driscoll. 2013. Successional specialization in a reptile community cautions against widespread planned burning and complete fire suppression. Journal of Applied Ecology 50: 1178-1186. doi: 10.1111/1365-2664.12119

Soule, M.E. 1991. Land use planning and wildlife maintenance: guidelines for conserving wildlife in an urban landscape. Journal of the American Planning Association 57: 313-323. doi: $10.1080 / 01944369108975502$

Soule, M.E., D.T. Bolger, A.C. Alberts, J. Wright, M. Sorice, and S. Hill. 1988. Reconstructed dynamics of rapid extinctions of chaparral-requiring birds in urban habitat islands. Conservation Biology 2: 75-92. doi: 10.1111/j.1523-1739.1988.tb00337.x 
Stanton, P.A. 1986. Comparison of avian community dynamics of burned and unburned coastal sage scrub. The Condor 88: 285-289. doi: 10.2307/1368874

Strahm, S., D. Marschalek, D. Deutschmand, and M. Berres. 2012. Monitoring the status of Hermes copper (Lycaena hermes) on conserved lands in San Diego County: 2010-2012. Prepared for San Diego Association Governments. US Geological Survey, Sacramento, California, USA.

Stromberg, M. 1997. Taricha torosa (California newt) response to fire. Herpetological Review 28: 82 .

Suarez, A.V., D.T. Bolger, and T.J. Case. 1998. Effects of fragmentation and invasion on native ant communities in coastal southern California. Ecology 79: 2041-2056. doi: 10.1890/0012-9658(1998)079[2041:EOFAIO]2.0.CO;2

Sugihara, N.G., J.W. van Wagtendonk, K.E. Shaffer, J. Fites-Kaufman, and A.E. Thode, editors. 2006. Fire in California's ecosystems. University of California Press, Berkeley and Los Angeles, USA. doi: 10.1525/california/9780520246058.001.0001

Taylor, R.S., S.J. Watson, D.G. Nimmo, L.T. Kelly, A.F. Bennett, and M.F. Clarke. 2012. Landscape-scale effects of fire on bird assemblages: does pyrodiversity beget biodiversity? Diversity and Distributions 18: 519-529. doi: 10.1111/j.1472-4642.2011.00842.x

Thompson, M.E., B.J. Halstead, G.D. Wylie, M. Amarello, J.J. Smith, M.L. Casazza, and E.J. Routman. 2013. Effects of prescribed fire on Coluber constrictor Mormon in coastal San Mateo County, California. Herpetological Conservaton and Biology 8: 602-615.

Turschak, G., C.J. Rochester, S.A. Hathaway, D.C. Stokes, C. Haas, and R.N. Fisher. 2010. Effects of large-scale wildfire on carnivores in San Diego County, California. US Geological Survey, Western Ecological Center, Sacramento, California, USA.

Underwood, E.C., and C.E. Christian. 2009. Consequences of prescribed fire and grazing on grassland ant communities. Environmental Entomology 38: 325-332. doi: 10.1603/022.038.0204

Underwood, E.C., and J.F. Quinn. 2010. Response of ants and spiders to prescribed fire in oak woodlands of California. Journal of Insect Conservation 14: 359-366. doi: 10.1007/ s10841-010-9265-7

Valentine, L.E., A. Reaveley, B. Johnson, R. Fisher, and B.A. Wilson. 2012. Burning in banksia woodlands: how does the fire-free period influence reptile communities? PLoS ONE 7: e34448. doi: 10.1371/journal.pone.0034448

Watson, S.J., R.S. Taylor, D.G. Nimmo, L.T. Kelly, A. Haslem, M.F. Clarke, and A.F. Bennett. 2012. Effects of time since fire on birds: how informative are generalized fire response curves for conservation management? Ecological Applications 22: 685-696. doi: 10.1890/ $11-0850.1$

Wirtz II, W.O. 1979. Effects of fire on birds in chaparral. Pages 114-124 in: D.L. Koch, editor. Proceedings of the Cal-Neva Wildlife Transactions. The Wildlife Society, 1-3 February 1979, Long Beach, California, USA. 